non-O157 recovered from domestic farm animals in rural communities in northwestern Mexico. Antimicrob Resist Infect Control. 2016;5:1-6. http://dx.doi.org/10.1186/s13756-015-0100-5

6. Centers for Disease Control and Prevention. NARMS now: human data 2016 [cited 2016 Oct 12]. http://wwwn.cdc.gov/ narmsnow

7. Ingram DD, Franco SJ. 2013 NCHS urban-rural classification scheme for counties. Vital Health Stat 2. 2014;(166):1-73.

8. Center for Healthcare Research and Transformation. Antibiotic prescribing and use. 2011 [cited 2016 Oct 12]. http://www.chrt.org/ document/antibiotic-prescribing-and-use/

9. Jacoby GA. Mechanisms of resistance to quinolones. Clin Infect Dis. 2005;41(Suppl 2):S120-6. http://dx.doi.org/10.1086/428052

10. Suda KJ, Hicks LA, Roberts RM, Hunkler RJ, Taylor TH. Trends and seasonal variation in outpatient antibiotic prescription rates in the United States, 2006 to 2010. Antimicrob Agents Chemother. 2014;58:2763-6. http://dx.doi.org/10.1128/AAC.02239-13

Address for correspondence: Shannon D. Manning, 1129 Farm Ln, Michigan State University, East Lansing, MI 48824, USA; email: mannin71@msu.edu

\section{White-Nose Syndrome Fungus in a 1918 Bat Specimen from France}

\author{
Michael G. Campana, Naoko P. Kurata, \\ Jeffrey T. Foster, Lauren E. Helgen, \\ DeeAnn M. Reeder, Robert C. Fleischer, \\ Kristofer M. Helgen
}

Author affiliations: Smithsonian Institution, Washington, DC, USA (M.G. Campana, N.P. Kurata, L.E. Helgen, R.C. Fleischer); University of New Hampshire, Durham, New Hampshire, USA (J.T. Foster); Bucknell University, Lewisburg, Pennsylvania, USA (D.M. Reeder); University of Adelaide, Adelaide, South Australia, Australia (K.M. Helgen)

DOI: https://doi.org/10.3201/eid2309.170875

White-nose syndrome, first diagnosed in North America in 2006, causes mass deaths among bats in North America. We found the causative fungus, Pseudogymnoascus destructans, in a 1918 sample collected in Europe, where bats have now adapted to the fungus. These results are consistent with a Eurasian origin of the pathogen.

$\mathrm{W}$ e report the earliest known historical incidence of the fungus Pseudogymnoascus (formerly Geomyces) destructans, detected in a museum specimen of a bat (Myotis bechsteinii) collected in France in 1918. This fungal pathogen causes white-nose syndrome (WNS) in bats (1). Since its introduction into eastern North America around 2006, WNS has devastated bat populations across the continent (2). P. destructans has also been found across the Eurasian landmass $(3,4)$ without documented mass bat deaths. Epidemiologic evidence among bats and fungal genetics indicate that the fungus has been recently introduced into North American bat populations (5-7).

To clarify the epidemiologic history of WNS and to investigate physical evidence of its presence in specific locations in the past, we screened 138 19th- and 20th-century bat specimens (housed at the National Museum of Natural History [USNM], Washington, DC) from North America (n $=41)$, Europe $(\mathrm{n}=83)$, and East Asia $(\mathrm{n}=14)$ for P. destructans DNA (online Technical Appendix, https://wwwnc.cdc. gov/EID/article/23/9/17-0875-Techapp1.pdf). We sampled dry museum skins and intact bodies stored in 70\% ethanol; some were originally fixed in formalin. We swabbed bat rostra and wings to collect potentially preserved $P$. destructans biomolecules and stored swabs in $100 \%$ ethanol until DNA extraction.

We extracted DNA in a dedicated ancient DNA laboratory at the National Zoological Park (Washington, DC) by using stringent protocols to prevent false positive results from modern DNA contamination (8). Before extraction, we removed swabs from the ethanol and let them air dry. We then let swabs digest overnight at $55^{\circ} \mathrm{C}$ in $600 \mu \mathrm{L}$ extraction buffer (1× Tris-EDTA buffer, $\mathrm{pH}$ 8.0, $0.019 \mathrm{mmol} / \mathrm{L}$ EDTA, $0.01 \mathrm{mmol} / \mathrm{L} \mathrm{NaCl}, 1 \% \mathrm{SDS}, 10 \mathrm{mg} / \mathrm{mL}$ DTT, and $1 \mathrm{mg} /$ $\mathrm{mL}$ proteinase $\mathrm{K})(8)$. Later extractions omitted DTT. We extracted digested samples twice in $600 \mu \mathrm{L}$ phenol and once in $600 \mu \mathrm{L}$ chloroform. We removed and concentrated the aqueous phase by using Amicon Ultra-4 $30 \mathrm{kDA}$ molecular weight cutoff columns (Millipore Sigma, Merck, Billerica, MA, USA) to a final volume of $\approx 250 \mu \mathrm{L}$. We included 1 extraction blank for every 10-11 historical samples.

We screened extracts for $P$. destructans by using a previously described species-specific quantitative PCR targeting $103 \mathrm{bp}$ (including primers) of the intergenic spacer region (9). Each extract was amplified in 2-8 replicate PCRs. Multiple, no-template controls $(2,3)$ were included in each PCR setup. Positive products from experiments in which quantifiable contamination $(>0.1$ genome equivalents $/ \mu \mathrm{L}$ sample) was observed in $\geq 1$ negative control were discarded; these experiments were repeated with fresh reagents.

One sample (USNM 231170) tested positive in 2 of 3 PCRs. We performed a second independent extraction on this sample. The replicate extraction tested positive in 4 of 5 PCRs. Two of the USNM 231170-positive PCR products were confirmed by using Sanger sequencing and comparison to publicly available $P$. destructans sequences in GenBank. These sequences were $100 \%$ identical to $P$. destructans sequences from North America (GenBank accession nos. JX270192.1 
and JX415267.1). In addition, 2 samples (USNM 15513 and 154222) yielded positive products in a single PCR each, but we were unable to replicate these results. No usable sequence was obtained from the USNM 15513 amplicon; the USNM 154222 sequence differed from the North American sequence by a single thymine deletion. DNA sequences were deposited in GenBank (accession nos. MF370925-6).

The 1 confirmed case of $P$. destructans infection among the museum samples we studied (USNM 231170, male, skin and skull) was in a Bechstein's bat (Myotis bechsteinii) collected on May 9, 1918, at Forêt de Russy, Centre-Val de Loire, France. This sequence is unlikely to represent $P$. destructans from a recently collected infected bat from North America because recently collected specimens have been purposefully stored with care in a separate room within the USNM mammal department, away from the historical bat collection. Furthermore, none of the historical samples of bats collected in North America, which are more likely to be cross-contaminated with potentially infected specimens compared with European specimens, tested positive for $P$. destructans.

We provide evidence of the presence of $P$. destructans $\approx 100$ years ago in Europe. In addition, we found no evidence of $P$. destructans in bats collected in eastern North America during 1861-1971. Although false negatives are highly likely because of the age, preparation, and storage of these specimens, these results are consistent with a Eurasian origin of the current WNS epidemic and strong association of the fungus with Eurasian bats of the genus Myotis $(3,6,10)$. Bats across Eurasia have adapted to $P$. destructans over more than a century, but the fungus was initially detected in North America during the early 21st century, and the bats on this continent have no immunity. This result extends the documented temporal occurrence of $P$. destructans as a batassociated fungus to the early 20th century and highlights the value of archived museum specimens for epidemiologic study of emerging fungal diseases, including WNS.

\section{Acknowledgments}

We thank Don Wilson and Nicole Edmison for assistance with specimens and sampling.

The Smithsonian Institution's Grand Challenges Consortia funded this research.

Dr. Campana is a computational genomics scientist at the Smithsonian Institution Conservation Biology Institute's Centers for Conservation Genomics. His research interests include analysis of animal and pathogen population genomics by using a combination of ancient DNA and computational genomics.

\section{References}

1. Lorch JM, Meteyer CU, Behr MJ, Boyles JG, Cryan PM, Hicks AC, et al. Experimental infection of bats with Geomyces destructans causes white-nose syndrome. Nature. 2011;480:376-8. http://dx.doi.org/10.1038/nature 10590

2. Frick W, Puechmaille SJ, Hoyt JR, Nickel BA, Langwig KE, Foster JT, et al. Disease alters macroecological patterns of North American bats. Glob Ecol Biogeogr. 2015;24:741-9. http://dx.doi.org/10.1111/geb.12290

3. Puechmaille SJ, Wibbelt G, Korn V, Fuller H, Forget F, Mühldorfer K, et al. Pan-European distribution of white-nose syndrome fungus (Geomyces destructans) not associated with mass mortality. PLoS One. 2011;6:e19167. http://dx.doi.org/10.1371/ journal.pone.0019167

4. Hoyt JR, Sun K, Parise KL, Lu G, Langwig KE, Jiang T, et al. Widespread bat white-nose syndrome fungus, northeastern China. Emerg Infect Dis. 2016;22:140-2. http://dx.doi.org/10.3201/ eid2201.151314

5. Warnecke L, Turner JM, Bollinger TK, Lorch JM, Misra V, Cryan PM, et al. Inoculation of bats with European Geomyces destructans supports the novel pathogen hypothesis for the origin of white-nose syndrome. Proc Natl Acad Sci U S A. 2012;109:6999-7003. http://dx.doi.org/10.1073/ pnas. 1200374109

6. Leopardi S, Blake D, Puechmaille SJ. White-nose syndrome fungus introduced from Europe to North America. Curr Biol. 2015;25:R217-9. http://dx.doi.org/10.1016/ j.cub.2015.01.047

7. Zukal J, Bandouchova H, Brichta J, Cmokova A, Jaron KS, Kolarik M, et al. White-nose syndrome without borders: Pseudogymnoascus destructans infection tolerated in Europe and Palearctic Asia but not in North America. Sci Rep. 2016;6:19829. Erratum in: Sci Rep. 2016;6:26049. http://dx.doi.org/10.1038/ srep19829

8. Fleischer RC, Olson SL, James HF, Cooper AC. Identification of the extinct Hawaiian eagle (Haliaeetus) by mtDNA sequence analysis. Auk. 2000;117:1051-6. http://dx.doi.org/10.1642/ 0004-8038(2000)117[1051:IOTEHE]2.0.CO;2

9. Muller LK, Lorch JM, Lindner DL, O'Connor M, Gargas A, Blehert DS. Bat white-nose syndrome: a real-time TaqMan polymerase chain reaction test targeting the intergenic spacer region of Geomyces destructans. Mycologia. 2013;105:253-9. http://dx.doi.org/10.3852/12-242

10. Wibbelt G, Kurth A, Hellmann D, Weishaar M, Barlow A, Veith M, et al. White-nose syndrome fungus (Geomyces destructans) in bats, Europe. Emerg Infect Dis. 2010; 16:1237-43. http://dx.doi.org/10.3201/eid1608.100002

Address for correspondence: Kristofer M. Helgen, University of Adelaide, Adelaide, Australia; e-mail kristofer.helgen@adelaide.edu.au 